\title{
Selenium Affects the $S$-alk(en)yl Cysteine Sulfoxides among Short-day Onion Cultivars
}

\author{
Dean A. Kopsell ${ }^{1}$ and William M. Randle ${ }^{2}$ \\ Department of Horticulture, The University of Georgia, Athens, GA 30602
}

\begin{abstract}
AdDitional Index words. Allium cepa, selenate, HPLC, pyruvic acid, trans(+)-S-(1-propenyl)-L-cysteine sulfoxide, (+)-Smethyl-L-cysteine sulfoxide, (+)-S-propyl-L-cysteine sulfoxide, S-2-carboxypropyl glutathione, $\gamma$-L-glutamyl-S-(1propenyl)-L-cysteine sulfoxide

Abstract. Four cultivars of onion (Allium cepa L. 'Primavera', 'Granex 33', 'Pegasus', and 'Sweet Success') were grown to maturity in modified nutrient solutions with or without $2.0 \mathrm{mg} \cdot \mathrm{L}^{-1} \mathrm{Na}_{2} \mathrm{SeO}_{4}\left(1.51 \mathrm{mg} \cdot \mathrm{L}^{-1} \mathrm{SeO}_{4}^{-2}\right)$. Selenium did not affect total flavor precursor content (ACSO) in 'Granex 33', 'Pegasus', and 'Sweet Success'. However, Se affected several individual ACSOs and precursor intermediates. Selenium decreased $\gamma$-L-glutamyl-S-(1-propenyl)-L-cysteine sulfoxide and trans(+)-S-(1-propenyl)-L-cysteine sulfoxide content in all four cultivars. $(+)-S$-Methyl-L-cysteine sulfoxide content was higher while (+)-S-propyl-L-cysteine sulfoxide content was lower with the added Se for two cultivars. Selenium lowered total bulb $S$ content in all cultivars, and increased the percentage of total $\mathrm{Saccumulated}$ as $\mathrm{SO}_{4}{ }^{-2}$ in three cultivars. The effect of Se on the flavor pathway was similar to that found when onions were grown under low S-concentrations. Flavor changes can be expected when onions are grown in a high Se environment, however, specific changes may be cultivar dependent.
\end{abstract}

Sulfur, an important plant macroelement, and Se, a nonessential plant element, have similar oxidation states and can substitute for one another in plants. To be utilized by plants, $\mathrm{SO}_{4}{ }^{-2}$ is absorbed by the roots, transported to the leaves, and assimilated into cysteine by a light-dependent reaction (Anderson, 1980). Cysteine can then be metabolized through a number of different plant pathways. The uptake of $\mathrm{SO}_{4}^{-2}$ is aided by a high affinity permease (Clarkson and Lüttge, 1991). When selenate $\left(\mathrm{SeO}_{4}^{-2}\right)$ is present in high concentrations, it can competitively inhibit $\mathrm{SO}_{4}^{-2}$ uptake because they compete for similar binding sites to the permease (Leggett and Epstein, 1956). Sulfate and $\mathrm{SeO}_{4}^{-2}$ also share a common uptake mechanism and are competitive substrates in the anaerobic microorganism Clostridium pasteuranum Winogradsky, (Bryant and Laishley, 1988). Once absorbed, $\mathrm{SeO}_{4}^{-2}$ can substitute for $\mathrm{SO}_{4}{ }^{-2}$ in the pathways leading to amino acid and protein synthesis (Anderson and Scarf, 1983). In doing so, Se analogues of cysteine and methionine are formed. Substitution of Se-amino acids into S-proteins, however, can alter the tertiary structure of Se-substituted proteins and cause drastic changes in catalytic activity (Brown and Shrift, 1982). These catalytic changes are considered a cause of Se toxicity in plants.

Onion (Allium cepa) flavors are dominated by a unique group of S-compounds derived from the precursors collectively known as $S$-alk(en)yl-L-cysteine sulfoxides (ACSO). The flavor precursors are nonprotein S-amino acids. The starting point of the proposed onion biosynthetic flavor pathway is the cysteine containing tripeptide glutathione (Lancaster and Boland, 1990). Glutathione, may become a temporary storage compound for reduced S (Rennenberg, 1984). Depending on conditions and variety, $S$ is then selectively metabolized through a series of peptides in the biosynthetic pathways leading to ACSO synthesis. Onions possess three of the four ACSOs identified in Allium, and include (+)$S$-methyl-L-cysteine sulfoxide (MCSO); (+)-S-propyl-L-cysteine sulfoxide (PCSO); and trans-(+)-S-(1-propenyl)-L-cysteine sulfoxide (1-PrenCSO). Two measurable intermediates leading to

Received for publication 27 July 1998. Accepted for publication 10 Feb. 1999. The cost of publishing this paper was defrayed in part by the payment of page charges. Under postal regulations, this paper therefore must be hereby marked advertisement solely to indicate this fact.

${ }^{1}$ Graduate assistant.

${ }^{2}$ Associate professor.
ACSO synthesis are $S$-2-carboxypropyl glutathione (2-carb) and $\gamma$-L-glutamyl-S-(1-propenyl)-L-cysteine sulfoxide (GPECSO). Onion flavor is experienced only following cellular disruption, where the enzyme alliinase is released from the vacuole and decomposes the ACSOs to produce pyruvate, ammonium, and the S-flavor compounds (Block, 1992).

Selenium is an essential micronutrient for maintaining mammalian health. Benefits attributed to proper Se nutrition range from immune system enhancement to cancer suppression (Schrauzer and Sacher, 1994; Vandenbrandt et al., 1993). This micronutrient is required for proper glutathione peroxidase function associated with antioxidant activity in cells. However, when consumed in high quantities, Se can accumulate in tissues and become toxic (Combs and Combs, 1986). The vegetables belonging to Allium were determined to be an excellent delivery system for Se that suppressed mammary cancer in mice (Ip et al., 1992; Ip and Lisk, 1994). A synergistic effect of the Allium S-compounds with the Se in cancer suppression was also reported. Selenium-flavor analogues exist in onion and garlic (Allium sativum L.) (Cai et al., 1994). Moreover, the Se-enriched onion and garlic had minimal Se accumulation in body tissues which were normally found with the standard Se supplement selenomethionine. Also, these Se-enriched onions and garlic did not alter the production and function of mammalian selenoenzyme (Ip and Lisk, 1994).

Because onions are a potentially beneficial source of Se in our diet, the effects of Se on the ACSO biosynthetic pathway and flavor development needs to be understood. Therefore, this study was undertaken to determine whether or not $\mathrm{SeO}_{4}{ }^{-2}$ would influence flavor precursor and precursor intermediate accumulation in bulb onions.

\section{Materials and Methods}

Plant culture. On 12 Dec. 1996, four short-day onion cultivars ['Primavera' (Peto Seeds, Saticoy, Calif.), 'Granex 33' (Asgrow Seeds, Kalamazoo, Mich.), 'Pegasus' (Asgrow Seeds, Kalamazoo, Mich.), 'Sweet Success' (Sun Seeds, Hollister, Calif.)] were seeded into growing cubes (Grodan A/S, Dk-2640, Hedehusene, Denmark). Fertilization was applied with $200 \mathrm{mg} \cdot \mathrm{L}^{-1}$ Peter's $20 \mathrm{~N}-$ 
8.8P-16.6K water-soluble fertilizer (Grace-Sierra Co., Malpitas, Calif.) as needed once cotyledons emerged. The seedlings were greenhouse grown $\left(25^{\circ} \mathrm{C}\right.$ day and $20^{\circ} \mathrm{C}$ night set points at $12 \mathrm{~h}$ for each temperature) for 5 weeks under natural photoperiods $\left(\approx 34^{\circ} \mathrm{N}\right.$ latitude). A broad-spectrum fungicide (Bravo 720 (chlorothalonil), Fermenta Plant Protection Co., Mentor, Ohio) was applied as needed.

Tanks $(2.74 \times 1.22 \times 0.18 \mathrm{~m})$ with prefabricated black liners were each filled with 500 L of a half-strength Hoagland's nutrient solution (Hoagland and Arnon, 1950). The S concentration was $246.5 \mathrm{mg} \cdot \mathrm{L}^{-1} \mathrm{MgSO}_{4} \cdot 7 \mathrm{H}_{2} \mathrm{O}\left(67.3 \mathrm{mg} \cdot \mathrm{L}^{-1} \mathrm{SO}_{4}^{-2}\right)$. Solutions were circulated and aerated using a Teel pedestal pump (model 3P611E; Dayton Electric Mfg. Co., Chicago, Ill.) attached to polyvinyl chloride (PVC) piping. Solution levels were maintained in the tanks with a mechanical float attached to a deionized water source. Styrofoam insulation boards were placed in the tanks to support the plants. The boards were suspended over the solutions with a PVC pipe framework. Wire fencing was placed $20.3 \mathrm{~cm}$ over the boards to support the foliage.

On 17 Jan. 1997, the onions were transferred to the Styrofoam boards and allowed to grow in the nutrient solution until $14 \mathrm{Feb}$. 1997, when $2.0 \mathrm{mg} \cdot \mathrm{L}^{-1} \quad \mathrm{Na}_{2} \mathrm{SeO}_{4}\left(1.51 \mathrm{mg} \cdot \mathrm{L}^{-1} \quad \mathrm{SeO}_{4}^{-2}\right)(\mathrm{ICN}$ Biochemicals, Cleveland, Ohio) was added to one tank. No Se was added to the other. The selenium level used in this experiment was based on results of Kopsell and Randle (1997a) who reported that $\mathrm{SO}_{4}{ }^{-2}$ use by onions was unaffected at $2.0 \mathrm{mg} \cdot \mathrm{L}^{-1} \mathrm{Na}_{2} \mathrm{SeO}_{4}$ concentrations, yet Se accumulation was highest among their treatments. The experimental design was a split plot with four replications and 14 plants per replication. The Se treatments were the main plots and onion cultivars were the subplots. A complete solution change was made every 2 weeks in each tank to restore the initial nutrient conditions of each treatment. Onions were grown and allowed to mature under natural photoperiods. Each cultivar was harvested when $50 \%$ of the plants had a soft pseudostem, indicating plant maturity. 'Primavera' and 'Sweet Success' were harvested 18 Apr. 1997, and 'Granex 33' and 'Pegasus' were harvested on 2 May 1997. Upon harvest, the roots were removed and the plants were allowed to dry at ambient greenhouse temperatures for $7 \mathrm{~d}$. Leaves were removed from the bulbs prior to analysis. Eight of the most uniform bulbs were selected for analysis. Wedges $(8-10 \mathrm{~mm})$ were cut longitudinally and grouped from each eight-bulb replication. One wedge group was used for total $\mathrm{Se}$, total $\mathrm{S}$, and $\mathrm{SO}_{4}{ }^{-2}$ determination, a second wedge group was used to measure flavor precursors and precursor intermediates, and a third wedge group was used to determine gross bulb pungency, as measured by total enzymatic pyruvic acid (EPY) content, and soluble solids content (SSC).

Total SE AND S DETERmination. The combined wedge groups were placed into paper bags and allowed to dry at $60{ }^{\circ} \mathrm{C}$ in a forced-air drying oven (model 630; National Appliance Co., Portland, Ore.) for no less than $48 \mathrm{~h}$. The dried tissue was then ground to pass a $0.5-\mathrm{mm}$ screen in a Cyclotec mill grinder (model 1093; Tector, Höganäs, Sweden). For total Se analysis, a wet acid digest was used. One gram of onion powder was placed into a 125 mL Erlenmeyer flask with $10 \mathrm{~mL}$ of concentrated nitric acid (70\% $\mathrm{HNO}_{3}$ ) and set on a hot plate (type 2200; Thermolyne, Dubuque, Iowa) for $4 \mathrm{~h}$ at $165^{\circ} \mathrm{C}$. A funnel test tube was inserted into each flask, and when filled with water, acted as a condenser to reduce sample loss during digestion. The flasks were then allowed to cool to room temperature $\left(\approx 26^{\circ} \mathrm{C}\right)$ and adjusted to a final volume of 50 $\mathrm{mL}$ with deionized water. The solutions were filtered through Whatman no. 1 filter paper (Maidstone, United Kingdom). Total Se was measured by graphite furnace atomic absorption spectro- photometry (GFAA) (model 4100ZL; Perkin Elmer Corp., Norwalk, Conn.), with a background detection limit of $4.0 \mu \mathrm{g} \cdot \mathrm{L}^{-1} \mathrm{Se}$. Total $\mathrm{S}$ in the plant tissue samples was determined using an $\mathrm{S}$ determinator (model SC-232; Leco Corp., St. Joseph, Mo.). One gram of onion powder was combined with vanadium pentoxide accelerator (Leco Corp.) and combusted at $1371{ }^{\circ} \mathrm{C}$ with $\mathrm{O}_{2}$. Total $\mathrm{S}$ was measured as $\mathrm{SO}_{2}$ with an infrared cell detector and quantified against $\mathrm{S}$ standards. Total $\mathrm{SO}_{4}{ }^{-2}$ was measured by modifying a turbidimetric method for total $\mathrm{S}$ determination (Gaines and Mitchell, 1979). Magnesium nitrate was not added to the onion powder before ashing so only tissue $\mathrm{SO}_{4}^{-2}$ was detected.

Flavor PRECURSORS AND INTERMEDIATE ANALYSIS. Precursor intermediates and ACSOs were extracted using a 12 methanol : 3 water solution, and an $80 \%$ ethanol solution according to Lancaster and Kelly (1983). Percent recovery throughout ion exchange fractionation, derivitization, and analysis was quantified by adding $S$-methyl glutathione $\left(\mathrm{MeGTH}\right.$; at $0.5 \mathrm{mg} \cdot \mathrm{g}^{-1}$ fresh weight), g-L-glutamyl-L-glutamic acid $\left(\gamma \mathrm{gG}\right.$; at $0.2 \mathrm{mg} \cdot \mathrm{g}^{-1}$ fresh weight), and ( \pm )-S-1-butyl-L-cysteine sulfoxide (BCSO; at 1.0 $\mathrm{mg} \cdot \mathrm{g}^{-1}$ fresh weight), as internal standards. An extracted sample representing $1 \mathrm{~g}$ fresh weight of bulb tissue ( $15 \mathrm{~mL}$ of extract) was placed into a test tube, along with each internal standard, and blown to dryness using ambient air, and redissolved in $1 \mathrm{~mL}$ of deionized-distilled water. A $0.5-\mathrm{mL}$ aliquot was then loaded onto an ion exchange column $(10 \times 40-\mathrm{mm}$; Bio-Rad, Hercules, Calif. with 3 mL Dowex $1 \times 8$ (200 to 400 mesh; Bio-Rad). Fractionation was carried out using acetic acid (HOAc) at four concentrations; $0.1,1,2$, and $5 \mathrm{M}$. The 0.1 and $2-\mathrm{M}$ fractions, containing the ACSOs and precursor intermediates, respectively, were collected and blown to dryness using ambient air. High-performance liquid chromatography (HPLC) sample preparation and analysis were carried out according to Randle et al. (1995). Each sample fraction was resuspended in $1 \mathrm{~mL}$ deionized-distilled water, and a $100-\mu \mathrm{L}$ sample was transferred to a $1.5-\mathrm{mL}$ microcentrifuge tube and reduced in vacuo using a concentrator (Centrivap; Labconco, Kansas City, Mo.). When dry, $250 \mu \mathrm{L}$ of 1 ethanol : 1 triethylamine (TEA) : 1 water was added to each sample and reduced again. Derivitization was performed by adding $100 \mu \mathrm{L}$ of freshly prepared 7 ethanol : 1 TEA : 1 phenylisothiocyanate (PITC) : 1 water to each sample. The samples were immediately flushed with nitrogen, capped, and held at room temperature for $20 \mathrm{~min}$. The derivitization solution was then removed in vacuo using the centrivap. Samples were again redissolved using $1.0 \mathrm{~mL}$ of 2 acetonitrile (HPLC grade) : 7 water and transferred to $1.5-\mathrm{mL}$ glass vials before injection on HPLC.

An HPLC separator module (2690; Waters, Milford, Mass.) with a 996 photodiode array detector was used for analysis. A Spheri-5 RP-18 5- $\mu \mathrm{m}, 250 \times 4.6-\mathrm{mm}$ column (Applied Biosystems, Foster City, Calif.) fitted with a $15 \times 3.2-\mathrm{mm} 7 \mu \mathrm{m}$ guard column (RP-18 Newgard; Applied Biosystems) was used for separation. The column temperature was maintained at $30{ }^{\circ} \mathrm{C}$. Eluted compounds were detected at $254 \mathrm{~nm}$ and data were collected and recorded using a personal computer with Millenium chromatography manager software (version 2.15.01; Waters). Peak assignment was carried out by comparing retention times with authentic standards (supplied by J.E. Lancaster, Crop and Food Research, Christchruch, New Zealand) as described by Randle et al. (1995). Solvents were A) aqueous acetonitrile (60\%) and B) $0.14 \mathrm{~m}$ sodium acetate with $0.05 \%$ TEA buffered to $\mathrm{pH} 6.5$ using glacial acetic acid. Solvents were filtered through a 0.45 mm Magna nylon filter (MSI, Westboro, Mass.). Forty-microliter sample volumes were injected onto the column. A flow rate of 1.0 $\mathrm{mL} \cdot \mathrm{min}^{-1}$ was used. The solvent gradient used was $15 \% \mathrm{~A}$ for 1.10 
Table 1. Bulb enzymatically formed pyruvic acid (EPY) ( $\mu \mathrm{mol} \cdot \mathrm{g}^{-1}$ fresh weight), percent soluble solids content (SSC), total bulb Se $\left(\mu \mathrm{g} \cdot \mathrm{g}^{-1} \mathrm{Se}\right.$ dry weight), total bulb S ( $\mu \mathrm{g} \cdot \mathrm{g}^{-1} \mathrm{~S}$ dry weight), total bulb $\mathrm{SO}_{4}\left(\mu \mathrm{g} \cdot \mathrm{g}^{-1} \mathrm{SO}_{4}\right.$ dry weight), and bulb $\mathrm{S}_{\text {as }} \mathrm{SO}_{4}$ (percent $\mathrm{S}_{\text {as }} \mathrm{SO}_{4}$ ) of four onion cultivars grown with or without $2.0 \mathrm{mg} \cdot \mathrm{L}^{-1} \mathrm{Na}_{2} \mathrm{SO}_{4}\left(1.51 \mathrm{mg} \cdot \mathrm{L}^{-1} \mathrm{SeO}_{4}^{-2}\right)$ in the nutrient solutions.

\begin{tabular}{|c|c|c|c|c|c|c|c|}
\hline$\overline{\text { Cultivar }}$ & Treatment & EPY & SSC & Bulb Se & Bulb S & $\mathrm{Bulb} \mathrm{SO}_{4}$ & $\mathrm{~S}(\%)$ as $\mathrm{SO}_{4}$ \\
\hline \multirow[t]{3}{*}{ Granex 33} & No Se & 6.3 & 8.4 & $\mathrm{ND}^{\mathrm{z}}$ & 8130 & 3310 & 41.16 \\
\hline & $\mathrm{Se}$ & 6.5 & 8.7 & 156.2 & 6730 & 2680 & 39.96 \\
\hline & Significance & NS & NS & $* * *$ & $* * *$ & NS & NS \\
\hline \multirow[t]{3}{*}{ Pegasus } & No Se & 5.0 & 9.2 & ND & 8610 & 2180 & 25.50 \\
\hline & $\mathrm{Se}$ & 3.8 & 9.0 & 143.3 & 7720 & 2920 & 37.87 \\
\hline & Significance & NS & NS & $* * *$ & NS & $* * *$ & $* *$ \\
\hline \multirow[t]{3}{*}{ Primavera } & No Se & 6.8 & 7.6 & ND & 8190 & 3340 & 40.84 \\
\hline & $\mathrm{Se}$ & 5.6 & 7.8 & 146.2 & 7500 & 4260 & 56.98 \\
\hline & Significance & NS & NS & $* * *$ & $* * *$ & $* *$ & $* * *$ \\
\hline \multirow[t]{3}{*}{ Sweet Success } & No Se & 10.7 & 9.0 & ND & 7420 & 2400 & 32.38 \\
\hline & $\mathrm{Se}$ & 9.0 & 9.7 & 143.2 & 6810 & 3530 & 52.06 \\
\hline & Significance & $* * *$ & $* * *$ & $* * *$ & $* *$ & $* *$ & $* *$ \\
\hline
\end{tabular}

${ }_{\mathrm{z} N D}=$ nondetected (below detection limits of GFAA.

Ns, ${ }^{*},{ }^{*},{ }^{* * *}$ Nonsignificant or significant at $P=0.10,0.05$, or 0.01 , respectively by a paired $t$ test.

$\min , 15 \%$ to $45 \%$ A over $21.1 \min , 45 \%$ to $100 \%$ A over 1 min, and a hold at $100 \% \mathrm{~A}$ for $14 \mathrm{~min}$. The flow was returned to the initial solvent gradient over $1 \mathrm{~min}$, and the column was reequilibrated for 12.9 min before the next sample was injected.

BULb PUNGENCY AND SOLUble SOLIDS ANALYSIS. Onion pungency for each treatment combination was determined using the pyruvic acid method of Randle and Bussard (1993). Enzymatically formed pyruvic acid (EPY) is routinely used to measure an onion's gross flavor intensity (Lancaster and Boland, 1990), and has been used to measure onion pungency in response to increasing Se concentrations (Kopsell and Randle, 1997b).

Wedges from each eight bulb group were juiced in a pneumatic press and subjected to the analysis. Juice was also applied to hand-held refractometer (Kernco, Tokyo, Japan) to measure soluble solids content (SSC). Soluble solids content is highly correlated with sugar content in onions (Jones and Mann, 1963).

Statistical analysis. Data were analyzed by the GLM procedure of SAS (Cary, N.C.). Differences among Se treatments were detected by paired $t$ test $(P=0.05$ or $P=0.01)$ with StatMost software (DataMost, Salt Lake City, Utah).

\section{Results and Discussion}

Onions grown in the Se supplemented nutrient solutions accumulated significant levels of Se. Bulb Se accumulation, however, differed only between $\mathrm{Na}_{2} \mathrm{SeO}_{4}$ treatments $(\mathrm{F}=5073.42 ; P=$ 0.0001). Bulb Se was not significantly different among cultivars, and Se averages ranged from 143.2 to $156.2 \mathrm{mg} \cdot \mathrm{g}^{-1}$ dry weight with $2.0 \mathrm{mg} \cdot \mathrm{L}^{-1}$ $\mathrm{Na}_{2} \mathrm{SeO}_{4}\left(1.51 \mathrm{mg} \cdot \mathrm{L}^{-1} \mathrm{SeO}_{4}^{-2}\right)$ in the nutrient solution (Table 1). When no Se was added to the nutrient solutions, bulb Se was below the limits of GFAA detection. The highest level of bulb Se previously reported with $2.0 \mathrm{mg} \cdot \mathrm{L}^{-1} \mathrm{Na}_{2} \mathrm{SeO}_{4}$ added to the nutrient solutions was $112.9 \mu \mathrm{g} \cdot \mathrm{g}^{-1} \mathrm{dry}$ weight (Kopsell and Randle, 1997b). In that experiment, however, the $\mathrm{S}$ concentration was $493 \mathrm{mg} \cdot \mathrm{L}^{-1}$ $\mathrm{MgSO}_{4} \cdot 7 \mathrm{H}_{2} \mathrm{O}\left(134.6 \mathrm{mg} \cdot \mathrm{L}^{-1} \mathrm{SO}_{4}^{-2}\right)$ of nutrient so- lution, while in the current experiment, the $\mathrm{S}$ concentration was $246.5 \mathrm{mg} \cdot \mathrm{L}^{-1} \mathrm{MgSO}_{4} \cdot 7 \mathrm{H}_{2} \mathrm{O}\left(67.3 \mathrm{mg} \cdot \mathrm{L}^{-1} \mathrm{SO}_{4}^{-2}\right)$. Selenium content in plant materials has been shown to decrease with increasing $\mathrm{SO}_{4}^{-2}$ in the growing environment (Barak and Goldman, 1997;

Fig. 1. Typical chromatograms for $S$-alk(en)yl-L-cysteine sulfoxides (ACSO) of 'Granex 33' onions grown with and without $2.0 \mathrm{mg} \cdot \mathrm{L}^{-1} \mathrm{Na}_{2} \mathrm{SeO}_{4}$. Identified peaks are 1) (+)-S-methyl-L-cysteine sulfoxide (MCSO), 2) trans-(+)-S-(1propenyl)-L-cysteine sulfoxide (1-PrenCSO), 3) (+)-S-propyl-L-cysteine sulfoxide (PCSO), and the internal standards 4) butyl-L-cysteine sulfoxide $(\mathrm{BCSO}(\mathrm{S})), 5)$ butyl-L-cysteine sulfoxide $(\mathrm{BCSO}(\mathrm{R}))$.
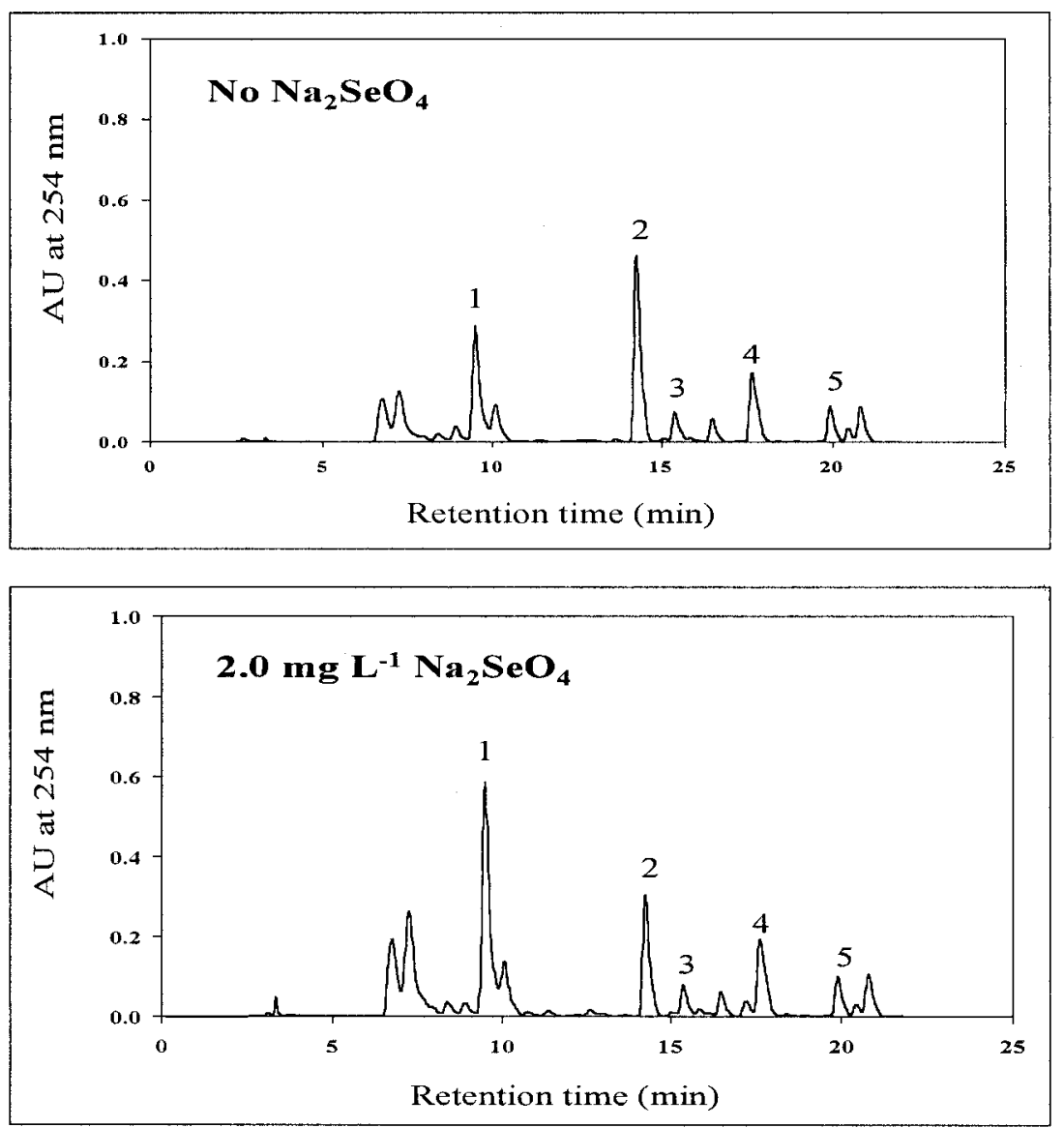
Table 2. Flavor precursors and precursor intermediates ${ }^{\mathrm{z}}\left(\mathrm{mg} \cdot \mathrm{g}^{-1}\right.$ fresh weight $)$ of four onion cultivars grown with and without $2.0 \mathrm{mg} \cdot \mathrm{L}^{-1} \mathrm{Na}_{2} \mathrm{SeO}_{4}$ $\left(1.51 \mathrm{mg} \cdot \mathrm{L}^{-1} \mathrm{SeO}_{4}^{-2}\right)$ in the nutrient solutions.

\begin{tabular}{|c|c|c|c|c|c|c|c|}
\hline$\overline{\text { Cultivar }}$ & Treatment & MCSO & 1-PrenCSO & PCSO & ACSO & $\gamma$ GPECSO & 2-carb \\
\hline \multirow[t]{3}{*}{ Granex 33} & No Se & 1.159 & 1.206 & 0.264 & 2.628 & 0.274 & 0.450 \\
\hline & $\mathrm{Se}$ & 1.535 & 0.745 & 0.205 & 2.485 & 0.191 & 0.463 \\
\hline & Significance & $* *$ & $* * *$ & $* *$ & NS & $* * *$ & NS \\
\hline \multirow[t]{3}{*}{ Pegasus } & No Se & 1.226 & 1.032 & 0.288 & 2.546 & 0.274 & 0.500 \\
\hline & $\mathrm{Se}$ & 1.312 & 0.713 & 0.320 & 2.673 & 0.225 & 0.480 \\
\hline & Significance & NS & $* * *$ & NS & NS & $*$ & $* * *$ \\
\hline \multirow[t]{3}{*}{ Primavera } & No Se & 1.382 & 1.233 & 0.270 & 2.884 & 0.259 & 0.489 \\
\hline & $\mathrm{Se}$ & 1.171 & 0.773 & 0.182 & 2.126 & 0.183 & 0.512 \\
\hline & Significance & NS & $* * *$ & $*$ & $*$ & $* *$ & NS \\
\hline \multirow[t]{3}{*}{ Sweet Success } & No Se & 1.031 & 1.285 & 0.264 & 2.580 & 0.212 & 0.488 \\
\hline & $\mathrm{Se}$ & 1.987 & 0.767 & 0.312 & 3.065 & 0.173 & 0.461 \\
\hline & Significance & $* *$ & $* * *$ & NS & NS & $* * *$ & NS \\
\hline
\end{tabular}

${ }^{\mathrm{z}} \mathrm{MCSO}=(+)-S$-methyl-L-cysteine sulfoxide, 1-PrenCSO $=$ trans(+)-S-(1-propenyl)-L-cysteine sulfoxide, PCSO $=(+)-S$-propyl-L-cysteine sulfoxide, $\mathrm{ACSO}=$ total $S$-alk(en)yl cysteine sulfoxides, $\gamma \mathrm{GPECSO}=\gamma$-L-glutamyl- $S$ - $(1$-propenyl)-L-cysteine sulfoxide, 2 -carb $=S$ - 2 -carboxypropyl glutathione.

Ns, ${ }^{*}, * *, * * * *$ Nonsignificant or significant at $P=0.10,0.05$, or 0.01 , respectively by a paired $t$ test.

Mikkelsen et al., 1989; Shrift, 1954). Onion Se content has been reported as high as $1000 \mu \mathrm{g} \cdot \mathrm{g}^{-1}$ dry weight with $8 \mathrm{mg} \cdot \mathrm{L}^{-1} \mathrm{Se}($ Barak and Goldman, 1997).

Selenium concentrations caused changes in the flavor precursor profile in onions (Fig. 1). However, we could not completely eliminate the possibility that the Se-analogs to the individual flavor precursors may have coeluted with the ACSOs during HPLC analysis. To date, we do not have direct quantitative measures for the Se-ACSO analogs. However, indirect evidence suggested that coelution was either trivial or separate elution occurred. First, total Se accumulation was between 43 and 54 times less than $\mathrm{S}$ accumulation among the cultivars tested (Table 1). Assuming the formation of Se analogs was proportional to total Se accumulation, Se analogs would be insignificant in the chromatograms if they coeluted. Second, the photodiode array detection of our method allows for a spectral analysis of important peaks. When we compared the ACSO peak spectral data from the Se-enriched plants with nonenriched plants, the probability that coeluted peak occurred was very low (data not shown). Spectral changes could be expected with the Se analogs. And third, several unidentified small peaks appeared on the Se-enriched chromatogram that did not appear on the S-only chromatograms (Fig 1.). In the future, identification and quantification of the Se-ACSO analogs will be important if Se-enriched Alliums are to be used as Se sources in our diets. Se-Cysteine-substituted proteins have the ability to alter the catalytic activity of enzymes in normal $S$ metabolism (Brown and Shrift, 1982), and can reduce the rate of protein synthesis (Eustice et al., 1981).

Total ACSO, PCSO, and 2-carb content did not differ significantly in the statistical model (Table 2). Methyl cysteine sulfoxide content in bulb tissues was significantly different between $\mathrm{Na}_{2} \mathrm{SeO}_{4}$ treatments $(\mathrm{F}=4.62 ; P=0.042)$ and for the $\mathrm{Na}_{2} \mathrm{SeO}_{4}$ treatments and cultivar interaction $(\mathrm{F}=3.14 ; P=0.044)$. 'Granex 33' and 'Sweet Success' MCSO content significantly increased with 2.0 $\mathrm{mg} \cdot \mathrm{L}^{-1} \mathrm{Na}_{2} \mathrm{SeO}_{4}(P=0.05$; Table 2$)$. With no $\mathrm{Na}_{2} \mathrm{SeO}_{4}$ in the solution, MCSOs were $44 \%, 48 \%, 47 \%$, and $40 \%$ of the total ACSO content for 'Granex 33', 'Pegasus', 'Primavera', and 'Sweet Success', respectively. At $2.0 \mathrm{mg} \cdot \mathrm{L}^{-1} \mathrm{Na}_{2} \mathrm{SeO}_{4}, \mathrm{MCSO}$ content increased to $62 \%, 49 \%, 55 \%$, and $65 \%$ of total ACSO for 'Granex 33', 'Pegasus', 'Primavera', and 'Sweet Success', respectively. Even though $\mathrm{S}$ was maintained at a level which should have been sufficient for proper growth and flavor development in both nutrient solutions, the elevated MCSO content with 2.0 $\mathrm{mg} \cdot \mathrm{L}^{-1} \mathrm{Na}_{2} \mathrm{SeO}_{4}$ followed the response of MCSO measured under low $\mathrm{S}$ concentrations (Randle et al., 1995). In that study, MCSO content increased relative to the other individual ACSO as $\mathrm{SO}_{4}^{-2}$ decreased in concentration to S-stress levels. Sufficiently high Se uptake and metabolism in onions thus gives the semblance of $S$ stress in the flavor pathway.

The concentration of 1-PrenCSO differed significantly among cultivars $(\mathrm{F}=5.83 ; P=0.004)$ and $\mathrm{Na}_{2} \mathrm{SeO}_{4}$ treatments $(\mathrm{F}=245.3$; $P=0.0001)$. Significant decreases in 1-PrenCSO content with 2.0 $\mathrm{mg} \cdot \mathrm{L}^{-1} \mathrm{Na}_{2} \mathrm{SeO}_{4}$ were found for all of the cultivars tested (Table 2 ). With no Se, 1 -PrenCSO was $46 \%, 41 \%, 43 \%$, and $50 \%$ of the total ACSO content for 'Granex 33', 'Pegasus', 'Primavera', and 'Sweet Success', respectively. With $2.0 \mathrm{mg} \cdot \mathrm{L}^{-1} \quad \mathrm{Na}_{2} \mathrm{SeO}_{4}$, 1PrenCSO decreased to $30 \%, 27 \%, 36 \%$, and $25 \%$ of the total ACSO content for 'Granex 33', 'Pegasus', 'Primavera', and 'Sweet Success', respectively. Further evidence of the affect of Se on the 1-PrenCSO pathway is evident with GPECSO, which is the penultimate compound leading to 1-PrenCSO synthesis. Concentrations of GPECSO differed among cultivars $(\mathrm{F}=6.50 ; P=$ $0.002)$ and between $\mathrm{Na}_{2} \mathrm{SeO}_{4}$ treatments $(\mathrm{F}=42.56 ; P=0.0001)$. Selenium significantly decreased GPECSO content for 'Granex 33', 'Primavera', and 'Sweet Success' (Table 2). Decreases in GPECSO content should cause decreased 1-PrenCSO content. These results are similar to the decreases in GPECSO and 1PrenCSO previously reported with decreased $\mathrm{S}$ concentration (Randle et al., 1995), giving further support to the effects of Se causing $\mathrm{S}$ stress like symptoms in the flavor pathway.

The effect of Se on S metabolism in onions was also evident when examining total bulb $\mathrm{S}$ and $\mathrm{SO}_{4}{ }^{-2}$ (Table 1). Bulb S accumulation differed among cultivars $(\mathrm{F}=8.22 ; P=0.0006)$ and $\mathrm{Na}_{2} \mathrm{SeO}_{4}$ treatments $(\mathrm{F}=30.85 ; P=0.0001)$. Selenate and $\mathrm{SO}_{4}{ }^{-2}$ can be antagonistic in plants (Arthur et al., 1992; Mikkelsen et al., 1989; Shrift, 1954), but the concentration of each ion in the nutrient solution is also important in determining how much of each ion is absorbed. Low Se concentrations in the nutrient solution actually enhanced $\mathrm{S}$ uptake by onions (Kopsell and Randle, 1997a). In this study, Se in the nutrient solution decreased total bulb S significantly in 'Granex 33', 'Primavera', and 'Sweet Success', displaying the antagonism of the competing ions (Table 1). Concurrently, $\mathrm{SO}_{4}{ }^{-2}$ content increased significantly in 'Pegasus', 'Primavera', and 'Sweet Success' when Se was added to 
the nutrient solution (Table 1). Therefore, not only did Se decrease total S uptake and accumulation, it also decreased the amount of $\mathrm{S}$ that entered the flavor pathway by storing a greater percentage of the absorbed $\mathrm{S}$ as $\mathrm{SO}_{4}^{-2}$. Excess $\mathrm{SO}_{4}{ }^{-2}$ is normally stored in the vacuole (Mengel and Kirkby, 1982) and increasing S concentration in the nutrient solutions will increase the percentage of total $\mathrm{S}$ that is stored as $\mathrm{SO}_{4}^{-2}$ (Randle et al., 1999).

Pungency, as indicated by EPY, differed among cultivars $(\mathrm{F}=$ $31.48 ; P=0.0001)$ and $\mathrm{Na}_{2} \mathrm{SeO}_{4}$ treatments $(\mathrm{F}=5.39 ; P=0.029)$. Bulb sugars, as indicated by SSC, differed among cultivars $(\mathrm{F}=$ 28.06; $P=0.0001)$ and $\mathrm{Na}_{2} \mathrm{SeO}_{4}$ treatments $(\mathrm{F}=2.95 ; P=0.098)$. Values for EPY and SSC were within the range previously reported for onions grown under similar $\mathrm{Na}_{2} \mathrm{SeO}_{4}$ treatments (Kopsell and Randle, 1997b). 'Sweet Success', however, was the only cultivar in which EPY and SSC differed significantly between $\mathrm{Na}_{2} \mathrm{SeO}_{4}$ treatments (Table 1).

Onions have the ability to accumulate large amounts of $\mathrm{Se}$ which, in turn, affects the S-based flavor precursor and precursor intermediates. The effect of Se on the flavor pathway was cultivar dependent, but Se generally decreased 1-PrenCSO and increased MCSO content. Selenium has also been shown to form analogs of the S-flavor compounds in the edible tissues of different Allium species (Cai et al., 1994). The ACSO changes resulting from Se supplementation would result in milder tasting onions because the heat and tear producing compounds arise from the decomposition of 1-PrenCSO (Block, 1992). These responses were comparable to the ACSO changes associated with low $\mathrm{S}$ concentrations in the nutrient solution. Changes in the flavor profile provides further evidence of the competitive nature of $\mathrm{S}$ and Se in plants, and needs to be considered if onions are to used as a Se delivery source to our diet.

\section{Literature Cited}

Anderson, J.W. 1980. Assimilation of inorganic sulfate into cysteine, p. 203-223. In: P.K. Stumpf and E.E. Conn (eds.). The biochemistry of plants-A comprehensive treatise. vol. 5. Amino acids and derivatives. Academic Press, New York.

Anderson, J.W. and A.R. Scarf. 1983. Selenium and plant metabolism, p. 241-275. In: D.A. Robb and W.S. Pierpoint (eds.). Metals and micronutrients: Uptake and utilization by plants. Academic Press, New York.

Arthur, M.A., G.Rubin, P.B. Woodbury, R.E. Schneider, and L.H. Weinstein. 1992. Uptake and accumulation of selenium by terrestrial plants growing on a coal fly ash landfill. Part 2 . Forage and root crops. Environ. Toxicol. Chem. 11:1289-1299.

Barak, P. and I.L. Goldman. 1997. Antagonistic relationship between selenate and sulfate uptake in onion (Allium cepa): Implications for the production of organosulfur and organoselenium compounds in plants. J. Agr. Food Chem. 45:1290-1294.

Block, E. 1992. The organosulfur chemistry of the genius AlliumImplications for the organic chemistry of sulfur. Angew. Chem. Intl. Educ. Engl. 31:1135-1178.

Brown, T.A. and A. Shrift. 1982. Selenium: Toxicity and tolerance in higher plants. Biol. Rev. 57:59-84.

Bryant, R.D. and E.J. Laishley. 1988. Evidence for two transporters of sulfur and selenium oxyanions in Clostridium pasteurianum. Can. J. Microbiol. 34:700-703.

Cai, X.J., P.C. Uden, E. Block, X. Zhang, B.D. Quimby, and J.J. Sullivan. 1994. Allium chemistry-Identification of natural-abundance organoselenium volatiles from garlic, elephant garlic, onion, and Chinese chive using headspace gas-chromatography with atomic-emission detection. J. Agr. Food Chem. 42:2081-2084.

Clarkson, D.T. and U. Lüttge. 1991. II. Mineral nutrition: Inducible and repressible nutrient transport systems. Progress Bot. 52:61-83.

Combs, Jr., G.F. and S.B. Combs. 1986. The role of selenium in nutrition. Academic Press, Orlando, Fla.

Eustice, D.C., F.J. Kull, and A. Shrift. 1981. Selenium toxicity: Aminoacylation and peptide formation with selenomethionine. Plant Physiol. 67:1054-1058.

Gaines, T.P. and G.A. Mitchell. 1979. Chemical methods for soil and plant analysis. Univ. Ga. Coastal Plain Expt. Sta. Agron. Hdbk. 1:1105

Hoagland, D.R. and D.I. Arnon. 1950. The water-culture method for growing plants without soil. Calif. Agr. Expt. Sta. Circ. 347.

Ip, C. and D.J. Lisk. 1994. Enrichment of selenium in Allium vegetables for cancer prevention. Carcinogenesis 15:1881-1885.

Ip, C., D.J. Lisk, and G.S. Stoewsand. 1992. Mammary cancer prevention by regular garlic and selenium-enriched garlic. Nutr. Cancer 17:279286.

Jones, H.A. and L.K. Mann, 1963. Onions and their allies: Botany, cultivation and utilization. Interscience Publ., New York.

Kopsell, D.A. and W.M. Randle. 1997a. Selenate concentration affects selenium and sulfur uptake and accumulation by 'Granex 33' onions. J. Amer. Soc. Hort. Sci. 122:721-726.

Kopsell, D.A. and W.M. Randle. 1997b. Short-day onion cultivars differ in bulb selenium and sulfur accumulation which can affect bulb pungency. Euphytica 96:385-390.

Lancaster, J.E. and M.J. Boland. 1990. Flavor biochemistry, p. 33-72. In: H.D. Rabinowitch and J.L. Brewster (eds.). Onions and allied crops. vol. 3. CRC Press, Boca Raton, Fla.

Lancaster, J.E. and K.E. Kelly. 1983. Quantitative analysis of the Salk(en)yl-L-cysteine sulphoxides in onions (Allium cepa L.). J. Sci. Food Agr. 34:1229-1235.

Leggett, J.E. and E. Epstein. 1956. Kinetics of sulfate absorption by barley roots. Plant Physiol. 31:222-226.

Mengel, K. and E.A. Kirkby. 1982. Principles of plant nutrition. Intl. Potash Inst. Bern, Switzerland.

Mikkelsen, R.L., A.L. Page, and F.T. Bingham. 1989. Factors affecting selenium accumulation by agricultural crops, p. 65-94. In L.W. Jacobs (ed.). Selenium in agriculture and the environment. Amer. Soc. Agron. Soil Sci. Soc. Amer., Madison, Wis.

Randle, W.M. and M.L. Bussard. 1993. Streamlining onion pungency analyses. HortScience 28:60.

Randle, W.M., D.E. Kopsell, D.A. Kopsell, and R.L. Snyder. 1999. Total sulfur and sulfate accumulation in onion is affected by sulfur fertility. J. Plant Nutr. 22:45-51.

Randle, W.M., J.E. Lancaster, M.L. Shaw, K.H. Sutton, R.L. Hay, and M.L. Bussard. 1995. Quantifying onion flavor compounds responding to sulfur fertility - Sulfur increases levels of alk(en)yl cysteine sulfoxides and biosynthetic intermediates. J. Amer. Soc. Hort. Sci. 120:10751081.

Rennenberg, H. 1984. The fate of excess sulfur in higher plants. Annu. Rev. Plant Physiol. 35:121-153.

Schrauzer, G.N. and J. Sacher. 1994. Selenium in the maintenance and therapy of HIV-infected patients. Chem. Bio. Interactions 91:199-205.

Shrift, A. 1954. Sulfur-selenium antagonism. I. Antimetabolite action of selenate on the growth of Chlorella vulgaris. Amer. J. Bot. 41:223-230.

Vandenbrandt, P.A., R.A. Goldbohm, P. Vantveer, P. Bode, E. Dorant, R.J.J. Hermus, and F. Sturmans. 1993. A prospective cohort study on selenium status and the risk of lung-cancer. Cancer Res. 53:4860-4865. 